DOI 10.18551/rjoas.2020-06.11

\title{
THE WORLD DECLINING ECONOMY AND CORONAVIRUS PANDEMIC: SYSTEMS SHOULD BE CONTINUED
}

\author{
Tariq Tawfeeq Yousif Alabdullah* \\ Department of Accounting, College of Administration and Economics, \\ University of Basrah, Iraq
}

Essia Ries Ahmed

College of Economics, Management and Information Systems, University of Nizwa, Oman

\author{
Mohamed Ibrahim Nor \\ SIMAD University, Mogadishu, Somalia
}

*E-mail: tariqtariq1984@gmail.com

\begin{abstract}
The appearance of coronavirus disease which is called COVID-19 in China on December 2019 has led to huge global outbreak that is strongly related to the bad health issue in the whole world. As of 27 March 2020, data from the World Health Organization have shown the countries, territories or areas with reported laboratory-confirmed COVID-19 cases and deaths. It shows that the most affected European country is Italy, where the total confirmed cases are 80539, while in Western Pacific Region, China was the first affected country by 82078 as total confirmed cases; however, the United States of America has total confirmed cases of 68334. Thus, the authorities of public health around the world must keep supervising the situation carefully, as the more the scientists can search about this deadly virus and its associated outbreak, the response and result will be better. Otherwise, the situation will go further to include damage to the whole world including the economic severe crisis. Based on that, the current study uniquely contributes to suggesting which systems should be continued under the unusual economic changes facing the whole world because of this awful pandemic. This study takes advantage of the 2020 financial crisis due to Coronavirus as a sudden and negative exogenous trauma that influenced the economies of all countries and the rest of the vital and social pillars in the world via focusing on Corporate Governance and Islamic Finance Industry as control systems and methods that should be continued in the time of the current pandemic. Noting that because of the current pandemic, there has been a shift to digital platform instead of keeping on using physical financial documents and this will lead to a diversity in purposes, highly efficient trade and secure.
\end{abstract}

\section{KEY WORDS}

COVID-19, economic impact, crisis, finance, economics.

Pandemic is a universal disease which had already happened many times like smallpox, tuberculosis, Plague, influenza pandemic, flu pandemic (H1N1), HIV/AIDS, and currently Coronavirus (COVID-19) pandemic. These pandemics lead to hassle business operations and economic growth around the world and continue as a universal phenomenon.

The current dilemma of respiratory tract infections is a picture of coronavirus appearing for the third time over two decades which is considered now as a serious pandemic (Guarner, 2020; Lai, Shih, Ko, Tang, \& Hsueh, 2020). In fact, this pandemic is not born today and this is confirmed and reported by Ksiazek, Erdman, Goldsmith, Zaki and Peret, (2003). Currently, the effect of the coronavirus pandemic is having a serious effect on the economy globally and has encouraged the policymakers looking for methods to have a positive response due to the fact that it is taking the world's economy towards the unknown. Chinese, for example, show that the sound policies are probably beneficial in fighting this pandemic 
and alleviating its severe impact (Yang, Peng, Wang, Guan, Jiang, Xu, \& Chang, 2020). In general, the world has faced a lot of confusion and crazy time. There are some scenes about this critical situation; for example, the American Federal Bank Reserve cuts interest rates to almost zero in an attempt to prop up US economy as revealed by The Guardian (2020) and also the global recession is almost certain, stock markets in the US are down well over $25 \%$ since its rise. The United States has allocated one trillion dollars as a stimulus package which is as a historic relief because coronavirus devastates economy. The pandemic also caused the UK to allocate 330 billion pounds as an emergency and stimulus package as a procedure to protect companies and incomes on a huge scale (Financial Times, 2020). Thus, several industries and projects are at risk for delays or damages because of Coronavirus epidemic as shown by Norris McLaughlin (2020). The problem of this study lies in dealing with which system should be continued by all companies in both developed and developing countries. The importance of the present study lies in analyzing the importance of going forward with applied corporate governance system and Islamic institutions around the world in all companies during the current crisis due to the challenge facing the world in stopping the sweeping wave that affected the world's economies negatively and this has led to a new global crisis that will be continued to affect, for unknown period of time, the world even if a solution and drug is found to stop the Coronavirus.

In the current study, and according to practical experiences in the literature, two systems and methods would be proposed to be appropriate to the circumstances of the current global crisis from a management, and Islamic perspective.

\section{CORPORATE GOVERNANCE AND CORONAVIRUS PANDEMIC}

Corporate governance system has been considered as one of the key theoretical approaches in the last twenty years. It is the extent of agency theory because one of its principles is to deal with the conflict of interest between stockholders and directors in the organization. It pursues to alleviate the conflict between these main parties. Other theories such as stakeholders theory was established to compensate for the shortage and shortfall in agency theory which was limited only to deal with the relationship between the agent and the principal, while the stakeholders theory included and dealt with all parties inside and outside the organization. Agency theory has been one of the main theoretical frameworks underpinning corporate governance during the last thirty years. Thus, under modern corporate governance, there is attention to empower board of directors' independency and also to protect investors. So, the important matter lies in the possibility for corporate governance to meet this challenge under the existence of Coronavirus Pandemic. So, it is very important in light of the current global crisis to cooperatively work as unified team that includes the convergence of interests of both internal and external parties that the organization includes and deals with. It is not the time to exchange the atmosphere of mistrust of owners, managers and stakeholders, but on the contrary, the situation requires the necessity of cooperation starting from the youngest employee to all parties inside and outside the organization. Scholars and those with specific specializations in corporate governance were interested in relying on various theories and approaches, including the above mentioned theory, the resource dependency theory and the stewardship theory whose role came all together to be practically employed in light of the climate of this crisis In this stage, there is a dire need to utilize such theories towards adopting them under the concept of corporate governance system to have sharing of business schedules including all management levels as a remedy to overcome and recover all difficulties in the current moments from one hand. Several essential things in this regard should be considered, from another hand. For instance: non-executive managers are board members with no other responsibilities for daily management of the organizations. CEO is one of the executive directors to be appointed as responsible for making key corporate decisions and managing operations of the whole organization. Under the current circumstances, there should be the same roles temporarily. Also, building confidence for the potential investors, investors, management and board of directors is very important. Moreover, making decisions should be 
by members of the board of directors together with sharing them with all management levels in the organization including employees. In addition, the rights of all shareholders should be taken into consideration to include the large shareholders and the minority of the shareholders. In that, they are human beings and they have rights and duties. Eventually, this is a challenging time; thus everyone has to join to be together to face this crisis.

Universally, corporate governance (CG) is strongly believed to be as a good control system having its root of origin that is utilized by all business levels in both developed and developing countries as a dynamic remedy to deal with firms' weak performance and low value (Alabdullah, Yahya \& Ramayah, 2014a). CG has gradually become a very vital subject to the firm and its profitability, specifically when the world has witnessed several failures, scandals and corruptions such as financial crises of 1997 and 2007 (Alabdullah, Alfadhl, Yahya, \& Rabi, 2014). Such crises and other, even the current ones, of Coronavirus have brought about a surprise for both developed and developing countries and given attention to all stakeholders to deal with firms having high level of corporate governance practice because such control system has its very high value in controlling and overseeing the firms (e.g., Ahmed, Alabdullah, Thottoli, \& Maryanti, 2020; Alabdullah, 2020; Alabdullah, 2019; Aebi, Sabato, \& Schmid, 2012; Alabdullah, 2016a, 2016b, 2016c, 2017, 2018; Alabdullah \& Alasadi; Alabdullah , Laadjal, Ries, \& Al-Asadi, 2018; Alabdullah, Ries, , \& Nor, 2019; Alabdullah, Ries, \& Thottoli, 2019; Alabdullah, Nor, \& Ries, 2018; Alabdullah, Ahmed, \& Nor, 2018; Alabdullah, Yahya, Nor, \& Majeed, 2016; Alabdullah, Yahya, \& Ramayah, 2014b; Srivastava and Kathuria, 2020). Scholars, such as Chen, Chen, and Wei (2009) show that recently the evidence as advocated in the previous studies by supporting the notion that the corporate governance alleviates cost of agency, leading to consolidate the point of view stating: the better the CG mechanisms, the more enhanced the firm performance and the more promoted firm value.

\section{ISLAMIC FINANCIAL INSTITUTIONS AND CORONAVIRUS PANDEMIC}

In light of the extraordinary circumstances, coronavirus keeps awfully spreading globally and leaves a swath of economic disruption on its way. Several Islamic finance umbrella organizations have started assessing the potential damage the virus has on Islamic finance and banking and the halal industry as a whole. Shariah, that regulates all Islamic financial tools and investments and its screening methodology, prohibits unethical businesses and practices that are similar to the negative screening methodology adopted by the socially responsible investment which makes both of them connected to Social Finance. Islamic Financial Market (IFM) plays a crucial role in driving progress and growing the size of the Islamic Finance industry while also standardizing the approach between banks. Banks and Islamic financial institutions in the Middle East are competing to gain a larger portion of the global transaction banking market, which was set to be worth more than $\$ 500$ billion by 2025 (ZAWYA 2020). But as a result of the COVID-19, this demand has dropped off considerably and the impact is being felt globally. However, with COVID-19 taking a toll on all sectors of trade and economy, the Islamic financial institutions are not wasting any time to ramp up reliance on technology. So, the majority of IFIs are now executing more Islamic trade finance transactions through their digital platform, which allows for secure, seamless, highly efficient trade finance transactions without the need for a physical exchange of documents. Indonesia's Islamic fin-techs downgrade growth forecasts but plod on amid corona-virus crisis. The crisis has made greater demands of Islamic fin-techs, as more lenders demand more transparency (YOSI WINOSA, 2020).

Islamic financial institutions are needed because of their positive features in all circumstances whether in Pandemic, crisis, or even in stable situations in international and domestic financial markets in both developed and developing countries. Several works in the literature admit this reality; for example there was a wave of studies done in normal situations to investigate the role of efficiency of Islamic financial institutions and their financial instruments, such as contracts of Sukuk (See, Ahmed, Yahya, Haron, \& Mohamed, 2020; Ahmed, Islam, Alabdullah, \& bin Amran, 2018; Zarrouk, 2014;Ahmed, Islam, Alabdullah, \& 
Amran, 2019; Ahmed, Islam, \& Amran, 2019; Mensi, Tiwari \& Yoon, 2017; Ahmed, Islam, \& Amran, 2019; Asmild, Kronborg, Mahbub, \& Matthews, 2019; Ahmed, Islam, \& Alabdullah, 2014; Ahmed, Alabdullah, Amran, \& Yahya, 2018; Alexakis, Izzeldin, Johnes, \& Pappas, 2019; Ahmed, Islam, Zuqibeh, \& Alabdullah, 2014; Ahmed, \& Zuqibeh, 2013).

In the existing literature there are a number of pertinent studies that have examined Islamic financial institutions during financial crisis. For instance, Zarrouk, (2014) this research analyzed the performance of Islamic financial institutions in Gulf Cooperation Council (GCC) in order to evaluate the hit Islamic financial institutions after financial crisis. The findings of this study revealed that the financial crisis negatively affected the performance of Islamic financial institutions in GCC. Also this study found the liquidity and profitability of Islamic financial institutions were decreased drastically after the crisis. However, they took excessive risk during and after the financial crisis. A study done by Mensi, Tiwari and Yoon, (2017) attempted to examine the weak-form efficiency of Islamic stock markets. This study found that the level of market efficiency varies over time and decreases after market collapse. Asmild, Kronborg, Mahbub, and Matthews, (2019) explored the differences in inefficiency patterns for a set of Bangladesh Islamic banks from 2001 to 2015. The results of this study confirm the consensus finding that Islamic financial banks outperform traditional and commercial banks during the global financial crisis. Alexakis, Izzeldin, Johnes, and Pappas (2019) examine the productivity and performance of Islamic financial institutions and traditional banks in the GCC region over the 2006-2012 period that covers the global financial crisis. This study found that Islamic financial institutions exhibit worse cost and profit performance but are on par with regards to revenue performance compared to the conventional ones. Also, this study mentioned that the pronounced within-Islamic financial institutions group variation in technical efficiency and technology suggests that Islamic financial institutions are quite heterogeneous as a group. Alqahtani, and Mayes (2018) attempted to explore the outperformance of Islamic financial institutions and conventional banks in the time of financial crisis during the period 2000-2013. The findings of this study found that the difference between the two banking types was initially not significant during the global financial crisis, but Islamic financial institutions suffered a significantly higher level of financial instability than conventional banks. Therefore, small Islamic financial institutions demonstrated relatively better handling of the economic downturn than large Islamic financial institutions. Hence, while Islamic financial institutions may have escaped the consequences of highly volatile financial tools, they were not spared from a major shock in the real economic sectors.

\section{DISCUSSION OF RESULTS, LIMITATIONS AND RRECOMMENDATIONS}

Because of Coronavirus Pandemic, the world has witnessed severe awful elements that have hit the business and the economy in the whole world in short and long terms directly and indirectly. Where more realistic expectations indicate that the economy may not recover in the near future and may be continued for several months with negative effect due the travel barriers, movement of goods and merchandise continues to be restricted and suspended. The Organization for Economic Cooperation and Development expected that the global GDP growth might be decreased by $0.5 \%$ for 2020 . Expectations also indicate that the impact of the pandemic on the business sector, tourism, technology, manufacturing, assembly, supply and the global trade movement will be increased significantly, which will push thousands of large companies to reduce productions or apply temporary closure as what has happened in Europe, America, in addition to countries in the Middle East. Islamic finance is set to keep expanding in 2020 and beyond as the Middle East countries and Malaysia help drive growth in Shariah-compliant financial instruments; however, there are downside risks from the coronavirus (COVID-19) outbreak, according to rating agency Moody's. Islamic financial institutions play an important role in resource mobilization and smooth liquidity in the Islamic capital markets (ICMs) (Ahmed, Amran, \& Islam, 2018). Besides, IFIs contribute to the economic growth of countries through real sector development initiatives. According to Moody's, in the Middle East countries, Islamic finance penetration 
increased over the last decade to 44 percent as of September 2019 from 32 percent in December 2009. The main driver was retail demand for Shariah-compliant financial services, which powered strong financing growth of around 6.2 percent in compound annual terms in the last three years, compared with a 4.5 percent increase in conventional bank financing. Therefore, the recent COVID-19 crisis has demonstrated a shift away from the physical financial documents to a more digital platform that allows for secure, seamless, highly efficient trade finance transactions and diversification purposes.

Global crisis is real warning about the existence of a threat and collapse facing the economies of all countries in the world. In the current time of the COVID-19 Pandemic, increasing the integrity should be focused and realized by the companies through increasing the quality of financial disclosure because in doing so, this would increase the confidence that the investors always look for and also to show reliable information about such companies during the financial crisis in order to finally alleviate crash risk. Globally, several control systems and methods such as Corporate Governance and Islamic Finance Industry have proven their ability to positively affect the companies all over the world, in both developed and developing countries.

Corporate governance needs to be seen as a vital control system to solve difficult problems in the normal cases and circumstances as well as in the time of the COVID-19 pandemic and the economic crises associated with this pandemic, because when these issues appear, it gets credit for the companies to enhance their performance. This also can offer protection for the companies' reputation. Corporate governance doesn't need to be the proverbial tree in the forest if no one follows its principles and applies its mechanisms but that would lead to negative reflection for the companies' outcome due to missing such precise system. In addition, in order to sustain long-term career success for the companies, they must deliver consistent high-quality results for their profitability and other outcomes that should be visible to all other comparative companies. When corporate governance and control mechanisms are visible, companies' managers and other beneficiaries learn how useful and important corporate governance is and this can create performance and growth opportunities for the companies and the economy of the country in the presence of Coronavirus risk. In the current paper, based on the literature review, this study has theoretically evaluated which systems should be continued in the time that the world has faced decline in the economy due to the awful impact of Coronavirus Pandemic. This study has also evaluated that the financial stability has a positive impact through continuing applying both corporate governance and Islamic institution industry because both of them have shown and proved that their impact is positive in both pandemic/crisis and nonpandemic/ non-crisis periods.

The limitation of the current study is that it needs to be done empirically rather than theoretically only. Nonetheless, this study would do so but there is no uploading of financial statements by the listed companies in the majority of countries, if any, for the first quarter of 2020. Therefore, this study strongly recommended the future researchers to empirically investigate the two systems: corporate governance and Islamic institutions industry via collecting data about them for the first quarter of 2020 to be compared with the data of the last quarter for the year of 2019. Eventually, this study calls for a novel approach towards the companies whatever their sizes are to increase the commitments towards utilizing the two above mentioned systems and approaches to safeguard their interests and their sustainability in light of the economic recession. This study would be useful to financial institutions by taking into consideration the factors that will enhance their efficiency and performance through the time of some factors of COVID-19 pandemic associated with investors to achieve the ultimate goals of maximizing the profit and compliance with rules. Also, the current study may assist policymakers in central banks in general, to set wise and deliberate policies related to COVID-19 crisis risks, and to promote IFIs' commitment toward aggressively monitoring financial instruments issuers by applying Shariah-compliant criteria. Ultimately, such a procedure would enhance IFIs governance mechanisms' practices. 


\section{REFERENCES}

1. Aebi, V., Sabato, G., Schmid, M. (2012). Risk management, corporate governance, and bank performance in the financial crisis. Journal of Banking \& Finance 32, 3213-3226.

2. Ahmed, E. R., Alabdullah, T. T. Y., Thottoli, M. M., \& Maryanti, E. (2020). Does Corporate Governance Predict Firm Profitability? An Empirical Study in Oman. The International Journal of Accounting and Business Society, 28(1), 127-143.

3. Ahmed, E. R., Yahya, S. B., Haron, H., \& Mohamed, D. H. (2020). Operational definition for doubtful activities (Shubuhat) based on Islamic finance perspective. Journal of Islamic Marketing.

4. Ahmed, E. R., Islam, M. A., Alabdullah, T. T. Y., \& bin Amran, A. (2018). Proposed the pricing model as an alternative Islamic benchmark. Benchmarking: An International Journal, Vol. 25 No. 8, pp. 2892-2912.

5. Ahmed, E.R., Amran, A. and Islam, M.A. (2018), "Sukuk documentation and legitimacy: the role of shariah supervisory board as a moderator", Management, Vol. 5 No. 3, pp. 2240.

6. Ahmed, E. R., Islam, M. A., Alabdullah, T. T. Y., \& Amran, A. B. (2019). A qualitative analysis on the determinants of legitimacy of sukuk. Journal of Islamic Accounting and Business Research, Vol. 10 No. 3, pp. 342-368.

7. Ahmed, E. R., Islam, A., \& Amran, A. B. (2019). Examining the legitimacy of Sukuk structure via Shariah pronouncements. Journal of Islamic Marketing, Vol. 10 No. 4, pp. 1151-1166.

8. Ahmed, E. R., Islam, M. A., \& Alabdullah, T. T. Y. (2014). Islamic sukuk: Pricing mechanism and rating. Journal of Asian Scientific Research, 4(11), 640.

9. Ahmed, E. R., Islam, A., Zuqibeh, A., \& Alabdullah, T. T. Y. (2014). Risks management in Islamic financial instruments. Advances in Environmental Biology, 402-406.

10. Ahmed, E. R., Islam, A., \& Amran, A. B. (2019). Examining the legitimacy of Sukuk structure via Shariah pronouncements. Journal of Islamic Marketing.

11. Ahmed, E. R., \& Zuqibeh, A. (2013). The role of shariah supervisory board in the reviewing and supervision on takaful (islamic insurance). Insurance and Takaful Journal (INTAJ).

12. Ahmed, E. R., Alabdullah, T. T. Y., Amran, A., \& Yahya, S. B. (2018). Indebtedness Theory and Shariah Boards: A Theoretical Approach. Global Business and Management Research, 10(1), 127-134.

13. Alabdullah, T. T. Y. (2020). Management accounting insight via a new perspective on the risk Management companies profitability relationship. International Journal of Intelligent Enterprise, 7(4) in press.

14. Alabdullah, T. T. Y. (2019). Management Accounting and Service Companies' Performance: Research in Emerging Economies, Australasian Accounting, Business and Finance Journal, 13(4), 100-118. doi:10.14453/aabfj.v13i4.8

15. Alabdullah, T. T. Y. (2016a). Corporate Governance from The Perspective of The Past and The Present and The Need to Fill an International Gap. Risk Governance \& Control: Financial Markets \& Institutions 6.

16. Alabdullah, T. T. Y. (2016b). The Performance of Companies and The Board's Characteristics From the New Perspective of Manipulation Avoidance. Corporate Ownership \& Control 13, 279-286.

17. Alabdullah, T. T. Y. (2016c). Are Board Size and Ownership Structure Beneficial in Emerging Markets' Firms? Evidence From Jordan. International Journal of Management \& Information Systems (IJMIS) 20, 87-94.

18. Alabdullah, T. T. Y. (2017). Compensation committee, company board attributes, and company performance: The moderating effect of leadership position. Paper presented at the 2017 Wei International Academic Conference Proceedings, July 24-27, 2017, Business and Economics.

19. Alabdullah, T. T. Y. (2018). The relationship between ownership structure and firm financial performance. Benchmarking: An International Journal, 25(1), 319-333. 
20. Alabdullah, T. T. Y., Alfadhl, M. M. A., Yahya, S., \& Rabi, A. M. A. (2014). The Role of Forensic Accounting in Reducing Financial Corruption: A Study in Iraq. International Journal of Business and Management, 9 (1), ISSN 1833-3850 E-ISSN 1833-8119.

21. Alabdullah, T. T. Y., Laadjal, A., Ries, E., \& Al-Asadi, Y. A. A. (2018). Board Features and Capital Structure in Emerging Markets. Journal of Advanced Management Science, 6 (2).

22. Alabdullah, T. T. Y., Ahmed, E. R., \& Nor, M. I. (2019). Do board characteristics provide more enhancement for firm financial performance? A corporate governance perspective. In S. Esposito De Falco, F. Alvino, \& A. Kostyuk (Eds.), New challenges in corporate governance: Theory and practice (pp. 89-91). https://doi.org/10.22495/ncpr_25.

23. Alabdullah, T. T. Y., Ahmed, E. R., \& Muneerali, M. (2019). Effect of Board Size and Duality on Corporate Social Responsibility: What has Improved in Corporate Governance in Asia?. Journal of Accounting Science, 3(2), 121-135.

24. Alabdullah, T. T. Y., Nor, M. I., \& Ahmed, E. R. (2018). The determination of firm performance in emerging nations: Do board size and firm size matter? Management, 5(3), 57-66.

25. Alabdullah, T. T. Y., Ahmed, E. R., \& Nor, M. I. (2018). New Ideas from Management, Finance and Accounting Perspective: The Research for A New Link Between A Company's Outcome and Risk Management. 5th International Conference on New Ideas in Management, Economics and Accounting.

26. Alabdullah, T. T. Y., Yahya, S., Nor, M. I., \& Majeed, F. Q. (2016). An Investigation of Corporate Governance from A New Perspective: Examining the Financial Performance of Companies and The Impact of Executive Turnover. Corporate Board: Role, Duties \& Composition, 12(1).

27. Alabdullah, T. T. Y., Yahya, S., \& Ramayah, T. (2014a). Corporate Governance Development: New or Old Concept? European Journal of Business and Management, 6(7), 312-315.

28. Alabdullah, T. T. Y., Yahya, S., \& Ramayah, T. (2014b). Corporate Governance Mechanisms and Jordanian Companies' Financial Performance. Asian Social Science, 10(22), p247.

29. Alexakis, C., Izzeldin, M., Johnes, J., \& Pappas, V. (2019). Performance and productivity in Islamic and conventional banks: Evidence from the global financial crisis. Economic Modelling, 79, 1-14.

30. Alqahtani, F., \& Mayes, D. G. (2018). Financial stability of Islamic banking and the global financial crisis: Evidence from the Gulf Cooperation Council. Economic Systems, 42(2), 346-360.

31. Asmild, M., Kronborg, D., Mahbub, T., \& Matthews, K. (2019). The efficiency patterns of Islamic banks during the global financial crisis: The case of Bangladesh. The Quarterly Review of Economics and Finance, 74, 67-74.

32. Chen, Chen, Z., \& Wei, K. J. (2009). Legal protection of investors, corporate governance, and the cost of equity capital. Journal of Corporate Finance, 15(3), 273-289. doi: 10.1016/j.jcorpfin.2009.01.001

33. Ksiazek TG, Erdman D, Goldsmith CS, Zaki SR, Peret T, et al. (2003) A novel coronavirus associated with severe acute respiratory syndrome. $\mathrm{N}$ Engl J Med 348: 1953-1966

34. Mensi, W., Tiwari, A. K., \& Yoon, S. M. (2017). Global financial crisis and weak-form efficiency of Islamic sectoral stock markets: An MF-DFA analysis. Physica A: Statistical Mechanics and its Applications, 471, 135-146.

35. Srivastava, G., Kathuria, V. (2020). Impact of corporate governance norms on the performance of Indian utilities, Energy Policy,Volume 140,2020.

36. Zagorchev A., Gao L., 2015, Corporate governance and performance of financial institutions, "Journal of Economics and Business", 82.

37. Zarrouk, H. (2014). The Impact of the International Financial Crisis on the Performance of Islamic Banks in MENA Countries', The Developing Role of Islamic Banking and Finance: From Local to Global Perspectives (Contemporary Studies in Economic and Financial Analysis, Volume 95). 
38. The guardian (2020). Report from https://www.theguardian.com/business/2020/mar/15/ federal-reserve-cuts-interest-rates-near-zero-prop-up-us-economy-coronavirus

39. Financial Times (2020). From https://www.ft.com/content/79d19c62-1396-3763-8b42aaf1f091e336

40. Norris McLaughlin (2020). From https://norrismclaughlin.com/clb/2020/03/10/is-yourconstruction-project-at-risk-for-delays-or-damages-because-of-the-coronavirus/

41. ZAWYA, (2020). COVID-19: UAE's ADIB bids on digital to drive Islamic trade finance, 30 April, 2020. https://www.zawya.com/mena/en/business/story/COVID19_UAEs_ADIB bids_on_digital_to_drive_Islamic_trade_finance-ZAWYA20200430093314/

42. ZAWYA, (2020). Demand for gold ETFs up 300\% amid coronavirus crisis, 30 April, 2020. https://www.zawya.com/mena/en/markets/story/Demand_for_gold_ETFs_up_300_amid_ coronavirus crisis-ZAWYA20200430135155/

43. YOSI WINOSA, (2020). Indonesia's Islamic fintechs downgrade growth forecasts but plod on amid coronavirus crisis, 22 April 2020. https://www.salaamgateway.com/story/ indonesias-islamic-fintechs-downgrade-growth-forecasts-but-plod-on-amid-coronaviruscrisis 